\title{
Conversa com o editor
}

\author{
Etienne Alfred Higuet
}

Esta conversa será breve, pois dedicamos mais espaço à apresentação do dossiê sobre o centenário da conferência inaugural de Paul Tillich: Sobre a ideia de uma teologia da cultura. Só apresentaremos aqui os textos que não entraram no dossiê. Eles não estabelecem uma relação com o pensamento de Tillich, mas tratam de temáticas que condizem com o perfil da revista, centrado na relação entre religião e cultura.

Temos dois textos na Seção livre. No artigo intitulado Mulher e Igreja: a teologia feminista em face católica, os autores Vicente Gregorio de Sousa Filho, Conceição de Maria de Oliveira Miranda, Antonio Michel de Jesus de Oliveira Miranda e Érica Barros de Rodrigues discutem a Teologia Feminista, procurando desvelar a participação da mulher na Bíblia, na Igreja e suas relações com a sociedade, a partir de uma perspectiva histórica e teológica. Na Igreja Católica, o feminismo, à luz da Teologia Feminista, tem contribuído para uma maior visibilidade da mulher. A pesquisa realiza uma abordagem qualitativa de levantamento bibliográfico, que inclui as narrativas bíblicas, estudiosos da Teologia Feminista e alguns documentos oficiais da Igreja, em vista de nos fazer perceber que as mulheres historicamente têm estabelecido uma íntima relação com o Divino, revelando-o e testemunhando-o em sua vida, mesmo que o ideário patriarcal as tenha tentado intimidar.

$\mathrm{O}$ artigo de Julio César Pasqualinato Rodrigues: A origem do mal e o crepúsculo da razão, na obra do Rei de Amarelo de Robert W. Chambers: Teologia e literature na cultura popular contemporânea, aborda o tema da origem do mal a partir das referências apresentadas no gênero literário denominado "fantasia sombria" com foco na obra de Robert W. Chambers, o Rei de Amarelo. O objetivo do artigo é apresentar a hipótese de que as influências diretas do gênero remontam à experiência religiosa que se traduziu na filosofia gnóstica que ganhou 
notoriedade a partir do século 2 d.C. No final, o artigo faz alguns apontamentos sobre a influência desse gênero na literatura e cultura popular do mundo contemporâneo.

Enfim, apresentamos um artigo na seção "Comunicações": Uma correlação sobre o mito da queda em Platão e Paul Tillich, por Edson Pereira da Silva. O autor tem como objetivo geral tratar do o mito da queda na correlação entre o pensamento de Paul Tillich e o pensamento de Platão. O texto está delimitado em três tópicos, encontrando o seu ápice no último. No primeiro tópico, discorre sobre o método de Correlação de Paul Tillich como um instrumento na elaboração de perguntas e respostas para o problema da existência. No segundo, trata da transição da essência à existência. No terceiro, analisa o mito da queda.

O presente número é o trigésimo-quarto, completando dezenove anos da revista. Inteiramente digitalizada e em acesso livre, a nossa revista constitui doravante uma soma de informações sobre o pensamento de Paul Tillich, única no Brasil. Esperamos poder manter a nossa periodicidade semestral nos próximos anos, com a ajuda dos nossos autores: precisamos urgentemente de vocês!

Desejamos a todas e todos uma ótima leitura! 